\title{
GENETIC PROGRESS OF PHENOTYPIC RECURRENT SELECTION IN POPCORN
}

\author{
Progresso genético da seleção recorrente fenotípica em milho-pipoca \\ Hugo Junqueira Ematné1, João Cândido de Souza², Gustavo Barnabé Biudes ${ }^{3}$, \\ José Airton Rodrigues Nunes ${ }^{2}$, Fernando Lisboa Guedes ${ }^{2}$
}

\begin{abstract}
Popcorn is widely consumed in the south of Minas Gerais; however, up to now no specific breeding program for the region has been carried out. Recurrent selection (RS) is a viable alternative for breeding of this crop; nevertheless, it is necessary to frequently evaluate the progress achieved. Consequently, the purpose of this work was to assess the genetic progress obtained after two cycles of RS for the traits of popping expansion (PE) and grain yield (GY). Cycles one and two of the UFLA - E and UFLA - R populations, the original population (UFLA) and two controls were assessed. The experiment was conducted at the UFLA experimental farm in a randomized block design with eleven replications; ten agronomic traits, including PE and GY, were assessed. Gains from selection for the traits studied were observed, as well as that the type of kernel had an influence on the response for genetic progress for the PE trait and that the populations assessed exhibited potential for future selection cycles.
\end{abstract}

Index terms: Popcorn, popping expansion, grain yield.

\section{RESUMO}

O milho-pipoca é amplamente consumido no Sul de Minas Gerais, entretanto, até o momento, nenhum programa de melhoramento especifico para a região foi conduzido. A seleção recorrente (RS) é uma alternativa viável para o melhoramento da cultura, todavia faz-se necessário verificar frequentemente o progresso obtido. Por conseguinte, objetivou-se avaliar o progresso genético obtido após dois ciclos de RS para os caracteres capacidade de expansão (PE) e rendimento de grãos (GY). Foram avaliados os ciclos um e dois das populações UFLA - E e UFLA - R, a população original (UFLA) e duas testemunhas. O experimento foi conduzido na fazenda experimental da UFLA, no delineamento em blocos ao acaso com onze repetições, dez características agronômicas incluindo PE e GY foram avaliadas. Constataram-se ganhos com a seleção para os caracteres estudados, que o tipo de grão (pérola e espinho) influenciou na resposta do progresso genético para o caráter PE e que as populações avaliadas apresentam potencial para futuros ciclos seletivo.

Termos para indexação: Milho-pipoca, capacidade de expansão, rendimento de grãos.

(Received in march 9, 2012 and approved in march 27, 2012)

\section{INTRODUCTION}

Most of the popcorn consumed in Brazil is derived from imported cultivar seeds (SAWAZAKI et al., 2003; SCAPIM et al., 2006). There are few popcorn breeding programs in Brazil; in the south of Minas Gerais, popcorn is widely consumed and, up to now, there has been no specific breeding program for the region. The crop provides a high economic return, mainly in the informal economy, with profitability well above the common corn crop (RANGEL et al., 2011a).

Farmers in the south of Minas have their own corn populations and have grown them for many years. One of these populations is maintained by the Federal University of Lavras, MG, Brazil (UFLA). This population is well adapted and has a predominance of yellow kernels, although it has a mixture of kernel types. A breeding program based on this population, with a view toward improvement of popping expansion (PE), grain yield (GY) and of other agronomic traits, would therefore yield important insights.

As genetic control of PE and GY, among other traits, are assuredly polygenic, it is necessary to carry out successive selection cycles (recurrent selection) to achieve success (HALLAUER et al., 2010). In Brazil, recurrent selection (RS) has been successfully performed in popcorn in other conditions and using other populations (DAROS et al., 2004a; PACHECO et al., 2005; SANTOS et al., 2008; RANGEL et al., 2011a).

In RS programs, it is necessary to periodically assess if progress is occurring in the selection in the attempt to seek alternatives that can improve their efficiency (HALLAUER et al., 2010). In this context, the present study

1Universidade Federal de Lavras/UFLA - Departamento de Biologia/DBI - Cx. P. 34 - 37200-000 - Lavras - MG - Brasil - so_hugo85@yahoo.com.br 2Universidade Federal de Lavras/UFLA - Departamento de Biologia/DBI - Lavras - MG - Brasil

${ }^{3}$ Syngenta - Uberlândia - MG - Brasil 
was carried out for the purpose of assessing the progress obtained after two cycles of recurrent selection for PE and GY in the UFLA population.

\section{MATERIAL AND METHODS}

The UFLA popcorn population (as described above) was used; the population has been maintained for a long time and exhibits a mixture of kernel types. A sample was sown in the 2005/06 crop season; at harvest, two subsamples were separated according to the type of kernel, either rounded (pearl) (population "R"), or elongated (rice) type (population "E"). These two populations were submitted to recurrent selection (RS) separately.

The $\mathrm{R}$ and $\mathrm{E}$ populations were sown in separate fields and recombined. At harvest, 200 ears were assessed in relation to $\mathrm{PE}$ according to the modified method described by Matta and Viana (2001), and the 20 with greatest PE were selected. In the following crop year, recombination was carried out using the Irish method (PATERNIANI, 1993). For that purpose, each progeny (ear) was sown in a row and detassled at the time of flowering, and, at every three rows, an equal mixture of the 20 progenies was added, which constituted the pollination row. All the healthy ears were assessed in relation to PE, with the best 20 being selected. A sample of the seed mixture of all the ears assessed was stored, population of the first selection cycle (UFLA - R 1). The same procedure was adopted in the following crop season, obtaining the UFLA - R 2. An analogous procedure was adopted for the "E" population, obtaining the populations UFLA - E 1 and UFLA - E 2.

The original UFLA populations, UFLA - R 1, UFLA - R 2, UFLA - E 1, UFLA - E 2, and the controls IAC-112 (modified simple hybrid) and IAC-125 (top cross hybrid), were assessed in the 2008/09 crop year. The experiment was conducted in the municipality of Lavras, MG, Brazil, located at $21^{\circ} 12^{\prime}$ 'south and $44^{\circ} 58^{\prime}$ 'west and an altitude of 951 meters. The experimental design was randomized blocks with eleven replications. The plots had two three-meter rows, with between row spacing of 0.8 meters and five plants per linear meter. At the time of sowing, the equivalent of $400 \mathrm{Kg} \mathrm{ha}^{-1}$ of the formulation 8-28-16 $\left(\mathrm{N}^{-} \mathrm{P}_{2} \mathrm{O}_{5}-\mathrm{K}_{2} \mathrm{O}\right)+$ $0,5 \% \mathrm{Zn}$ was used. Top dressing was performed with ammonium sulfate at $300 \mathrm{Kg} \mathrm{ha}^{-1}$.

The following traits were assessed: $\mathrm{PH}-$ plant height; EH - ear height; MF - male flowering; FF - female flowering; $\mathrm{PR}$ - prolificacy rate; $\mathrm{ED}$ - ear diameter; $\mathrm{CD}$ cob diameter; $\mathrm{KL}$ - mean kernel length; GY - grain yield in tons per hectare obtained from the weight of grain from each plot with later transformation to tons per hectare, corrected by ideal stand of plants per plot (30 plants), by the covariance method (VENCOVSKY; CRUZ 1991), and for standard moisture of $13 \%$ and $\mathrm{PE}$ - popping expansion in $\mathrm{mL} \mathrm{g}^{-1}$, obtained by the ratio between the volume of popcorn expanded and the weight of the kernels. In each plot, two samples of 30 grams of grain were assessed in a $1000 \mathrm{~W}$ microwave for 2.5 minutes ( 150 seconds) according to the modified method described by Matta and Viana (2001). The expanded popcorn was measured in a $1000 \mathrm{~mL}$ graduated cylinder.

All the traits were submitted to analysis of variance (RAMALHO et al., 2005; CRUZ, 2006). The means were compared by the Scott and Knott test (1974). Selective accuracy was estimated in accordance with Resende and Duarte (2007). Contrasts of interest were estimated in accordance with Nogueira (2007). For estimating genetic progress, linear regression was obtained, with the dependent variable $(\mathrm{X})$ being the number of cycles and the independent variable $(\mathrm{Y})$ being grain yield and $\mathrm{PE}$ (RAMALHO et al., 2005).

\section{RESULTS AND DISCUSSION}

The climatic conditions of the 2008/09 crop season were favorable to the crop, especially regarding rain intensity and distribution in the period. The favorable climatic conditions plus the good experimental conditions resulted in good estimates regarding the information to be derived from the experiment, allowing verification by selective accuracy (Table 1), which quantifies the experimental accuracy, where values ranging from $38 \%$ to $92 \%$ are observed for the traits of plant height $(\mathrm{PH})$ and grain yield (GY) respectively. In synthesis, all the traits assessed whose $\mathrm{F}$ test exhibited significant differences for the genotype variation source (Table 1) presented accuracy estimates of high precision, according to the classification of Resende and Duarte (2007).

Through the summary of analysis of variance, significant differences $(\mathrm{P}<0.05)$ were observed for the genotype effect in the evaluated traits, with the exception of kernel length (KL) (Table 1), showing the existence of genetic variability among the genotypes assessed, a fact which was expected since the populations are being compared with the controls. Nevertheless, when the population variation source is observed, with this being a refinement of the genotype source, it may be seen that the GY, prolificacy rate (PR), female flowering (FF) and male flowering (MF) traits exhibited significant differences $(\mathrm{P}<0.05)$, as well as the popping expansion $(\mathrm{PE}) \operatorname{trait}(\mathrm{P}<0.07)$ (Table 1). In other words, the populations' present genetic 
variability for the main agronomic traits assessed, as was to be expected, since these populations were in different breeding stages. Variability is fundamental to obtain success in the next selective cycles. For the PR trait, the mean grouping test formed two groups (Table 1), highlighting the populations UFLA - R 2 and UFLA - E 2 for exhibiting prolificacy estimates statistically similar to the hybrids (IAC-112 and IAC-125) and greater than the other populations. From the results, it may be inferred that the truncated selection for the PE trait favorably responds to increase the PR. Viana (2007) observed values ranging from 0.96 to 1.42 comparing three selection cycles of the Beija-Flor population and the original population.

Although the PR estimates found by Viana (2007) in the different cycles are in a general way greater than those observed in the present study, we must highlight that the author used the hybrid IAC-112 as a control, which exhibited a PR much greater than that found in this study.
Nevertheless, the low PR observed may be a consequence of the high population density and/or the high quantity of rainwater which occurred, which may have contributed to leaching of soil nitrogen, with reduction in the PR as a consequence.

In the traits of ear diameter (ED) and cob diameter (CD), the formation of two groups was also observed (Table 1), particularly the populations (exception of UFLAR 1), which exhibited ED superior to the controls and CD equivalent to the hybrid IAC-125; however, the genotypes were not differentiated in regards to the KL trait. Considering that the controls are commercial hybrids, which already produce kernels with good length, it may be said that the populations do not have a problem in regard to the length of their kernels. For the PH trait, the populations exhibited smaller plants in relation to the hybrid IAC-112 (Table 1), a favorable characteristic in breeding programs, above all from the agronomic point of view.

Table 1 - Summary of analysis of variance, orthogonal contrasts and means of grain yield in ton ha ${ }^{-1}$ (GY), popping expansion in $\mathrm{mL} \mathrm{g}^{-1}(\mathrm{PE})$, prolificacy rate (PR), ear diameter in $\mathrm{cm}(\mathrm{ED})$, cob diameter in $\mathrm{cm}(\mathrm{CD})$, kernel length in $\mathrm{cm}(\mathrm{KL})$, plant height in $\mathrm{cm}(\mathrm{PH})$, ear height in $\mathrm{cm}(\mathrm{EH})$, female flowering in days (FF), and male flowering in days (MF), assessed in the UFLA, UFLA - E 1 and 2, UFLA - R 1 and 2 populations and in the controls IAC-112 and IAC-125, Lavras, MG, in the $2008 / 2009$ crop year.

\begin{tabular}{|c|c|c|c|c|c|c|c|c|c|c|c|}
\hline \multirow{2}{*}{ Genotypes } & \multicolumn{11}{|c|}{ Traits } \\
\hline & GY & $\mathrm{PE}$ & PR & ED & $\mathrm{CD}$ & KL & \multicolumn{2}{|c|}{$\mathrm{PH}$} & $\mathrm{EH}$ & FF & $\mathrm{MF}$ \\
\hline UFLA & $2.61 \mathrm{~b}$ & $20.10 \mathrm{~b}$ & $0.83 \mathrm{~b}$ & $3.20 \mathrm{a}$ & $1.80 \mathrm{a}$ & $1.39 \mathrm{a}$ & \multicolumn{2}{|c|}{$209 \mathrm{~b}$} & $114 \mathrm{~b}$ & $58 \mathrm{~b}$ & $54 \mathrm{~b}$ \\
\hline UFLA - E 1 & $2.62 \mathrm{~b}$ & $21.00 \mathrm{~b}$ & $0.83 \mathrm{~b}$ & $3.15 \mathrm{a}$ & $1.79 \mathrm{a}$ & $1.36 \mathrm{a}$ & \multicolumn{2}{|c|}{$210 \mathrm{~b}$} & $116 \mathrm{~b}$ & $59 \mathrm{a}$ & $56 \mathrm{a}$ \\
\hline UFLA - R 1 & $1.97 \mathrm{c}$ & $22.23 \mathrm{~b}$ & $0.76 \mathrm{~b}$ & $3.08 \mathrm{~b}$ & $1.73 \mathrm{a}$ & $1.35 \mathrm{a}$ & \multicolumn{2}{|c|}{$203 \mathrm{~b}$} & $111 \mathrm{~b}$ & $59 a$ & $56 a$ \\
\hline UFLA - E 2 & $3.07 \mathrm{a}$ & $22.18 \mathrm{~b}$ & $0.95 \mathrm{a}$ & $3.22 \mathrm{a}$ & $1.81 \mathrm{a}$ & $1.41 \mathrm{a}$ & \multicolumn{2}{|c|}{$216 b$} & $120 \mathrm{a}$ & $58 \mathrm{~b}$ & $54 \mathrm{~b}$ \\
\hline UFLA - R 2 & $2.94 \mathrm{a}$ & $23.90 \mathrm{a}$ & $0.97 \mathrm{a}$ & $3.13 \mathrm{a}$ & $1.79 \mathrm{a}$ & $1.34 \mathrm{a}$ & \multicolumn{2}{|c|}{$213 b$} & $122 \mathrm{a}$ & $60 \mathrm{a}$ & $55 \mathrm{a}$ \\
\hline IAC-112 & $3.28 \mathrm{a}$ & $24.80 \mathrm{a}$ & $1.08 \mathrm{a}$ & $3.02 \mathrm{~b}$ & $1.64 \mathrm{~b}$ & $1.37 \mathrm{a}$ & \multicolumn{2}{|c|}{$233 \mathrm{a}$} & $127 \mathrm{a}$ & $56 \mathrm{~b}$ & $54 \mathrm{~b}$ \\
\hline IAC- 125 & $3.04 \mathrm{a}$ & $23.90 \mathrm{a}$ & $0.97 \mathrm{a}$ & $3.03 \mathrm{~b}$ & $1.73 \mathrm{a}$ & $1.27 \mathrm{a}$ & \multicolumn{2}{|c|}{$211 b$} & $116 \mathrm{~b}$ & $57 \mathrm{~b}$ & $53 \mathrm{~b}$ \\
\hline General mean & 2.80 & 22.59 & 0.91 & 3.12 & 1.76 & 1.36 & \multicolumn{2}{|c|}{214} & 118 & 58 & 54 \\
\hline Mean of populations & 2.64 & 21.90 & 0.86 & 3.16 & 1.78 & 1.37 & \multicolumn{2}{|c|}{210} & 117 & 58 & 55 \\
\hline Mean of controls & 3.16 & 24.35 & 1.03 & 3.03 & 1.69 & 1.32 & \multicolumn{2}{|c|}{222} & 122 & 56 & 54 \\
\hline QM(Genotypes) & $2.09 * *$ & $32.13 * *$ & $0.133 * *$ & $0.065^{*}$ & $0.038 *$ & $0.021^{\mathrm{ns}}$ & \multicolumn{2}{|c|}{$960.22 * *$} & $333.94 *$ & $18.70 * *$ & $9.05 * *$ \\
\hline QM(Populations) & $2.00 * *$ & $22.01^{\#}$ & $0.085 * *$ & $0.031^{\mathrm{ns}}$ & $0.012^{\mathrm{ns}}$ & $0.008^{\mathrm{ns}}$ & \multicolumn{2}{|c|}{$256.84^{\mathrm{ns}}$} & $216.25^{\mathrm{ns}}$ & $8.63^{*}$ & $5.88 * *$ \\
\hline \multirow[t]{2}{*}{$r_{g g}$} & $92 \%$ & $74 \%$ & $88 \%$ & $52 \%$ & $44 \%$ & - & \multicolumn{2}{|c|}{$38 \%$} & $63 \%$ & $82 \%$ & $89 \%$ \\
\hline & \multicolumn{6}{|c|}{ Contrast for PE } & \multicolumn{2}{|c|}{$\mathrm{QM}$} & \multicolumn{2}{|c|}{$\mathrm{F}$ (calculated) $\mathrm{F}$} & $\operatorname{Pr}>\mathrm{F}$ \\
\hline $\mathrm{Y}(1)$ & \multicolumn{6}{|c|}{ UFLA vs UFLA - R 2} & \multicolumn{3}{|c|}{77.53} & 9.06 & 0.005 \\
\hline $\mathrm{Y}(2)$ & \multicolumn{6}{|c|}{ UFLA vs UFLA - E 2} & \multicolumn{3}{|c|}{23.01} & 2.69 & 0.108 \\
\hline $\mathrm{Y}(3)$ & \multicolumn{7}{|c|}{ UFLA - E 1 and UFLA - R 1 vs UFLA - E 2 and UFLA - R 2} & \multicolumn{2}{|c|}{61.67} & 7.20 & 0.010 \\
\hline
\end{tabular}

QM: mean square and $r_{g g}$ : selective accuracy.

Means followed by the same letter do not differ among themselves by the Scott and Knott test at the level of $5 \%$ probability. ns, \#, * and **: non significant, significant at $7 \%, 5 \%$ and $1 \%$, respectively, by the $\mathrm{F}$ test. 
For the MF and FF traits, although the formation of two groups has occurred (Table 1), the variation observed in days was small, for both male and female flowering. Comparing the mean of the populations with the mean of the controls, a difference of 2 and 1 days is observed for the FF and MF respectively, which characterizes the populations as early cycle, as the controls have this classification.

For the PE trait, the formation of two groups is seen, especially regarding UFLA - R 2, which was superior to the other populations and statistically similar to the commercial hybrids (Table 1). Note that the population that has the round or pearl type kernel " $\mathrm{R}$ " had a selection response superior to the population that has the rice or clove of garlic type kernel "E". This fact was ratified by the orthogonal contrasts $\mathrm{Y}(1)$ and $\mathrm{Y}(2)$, which show that UFLA is different from UFLA - R 2 with $99 \%$ probability, while UFLA is different from UFLA - E 2 with $88 \%$ probability; in other words, the phenotypic selection practiced for PE exhibited positive and superior responses for the round type kernel population versus the rice type (Table 1). By contrast, for Y(3) it can be noted that the selection practiced for PE in the first cycle of both the populations led immediately to positive effects in the second cycle (Table 1).

Nevertheless, it should be noted that the populations are in the initial stages of breeding with expectations of gains in future cycles. The estimates of the PE populations were always above $21 \mathrm{mLg}^{-1}$ (Table 1), these being higher than those obtained by Matta and Viana (2003); and were always superior when the authors compared the $\mathrm{BF}, \mathrm{BFse}$ and $\mathrm{BFc} 1$ populations in competitive tests. The general mean of $\mathrm{PE}$ of the different populations (Table 1) was quite similar to the general mean of the third recurrent selection cycle obtained by Santos et al. (2008) in the population UNB-2U and lower estimates of the fourth and fifth selection cycle of the population UNB-2U (FREITAS JÚNIOR et al., 2009, RANGEL et al., 2011a).

According to Hallauer et al. (2010) three cycles of recurrent selection is not sufficient to observe expressive gains for some corn characteristics. However, considering the regression equations presented in Figure 1(A), gains are seen for PE selection in only two assessed cycles. For the UFLA - R population, the estimate of the angular coefficient of the straight line $(\mathrm{P}<0.05)$ allows one to infer that the gain was $8.58 \%\left(1.88 \mathrm{~mL} \mathrm{~g}^{-1}\right)$ at each selection cycle with $\mathrm{R}^{2}>0.99$, while for the UFLA - E population, the estimate of the angular coefficient of the straight line $(\mathrm{P}<0.1)$ allows one to infer that the gain was $4.65 \%(1.02$ $\mathrm{mL} \mathrm{g}^{-1}$ )at each selection cycle with $\mathrm{R}^{2}>0.99$. This suggests that the phenotypic recurrent selection for PE in the recombination lot is an effective strategy, concurring with reports from Matta and Viana (2003), since with only two selection cycles, it was possible to observe expressive gains.

For the GY trait, the formation of three groups was observed (Table 1), with the populations UFLA - R 2 and UFLA - E 2 standing out in relation to the others, and being statistically similar to the controls. This is an encouraging fact because the selection practiced for PE did not present an unfavorable response to the GY trait, as has occurred to other conditions in other populations with more or less intensity (DAROS et al. 2004b; RANGEL et al., 2011b).

Comparing the mean yield estimates of the second cycle of the two populations (Table 1) with the estimates obtained by Viana (2007) with Beija-Flor, Beija-Flor C1 SE, Beija-Flor C2 SE and Beija-Flor C3 SE populations, and with the general mean of different hybrids and cultivars obtained by Vieira et al. (2009), the superiority of the populations UFLA - R 2 and UFLA - E 2 is clear. Through analysis of the linear regression equations presented in Figure 1(B), a linear adjustment for the population UFLA - $\mathrm{R}$ is not seen, whereas the population UFLA - E exhibits a linear adjustment $\left(\mathrm{R}^{2}>0.76\right)$; however the angular coefficient of the straight line was not significant.

Analyzing Table 1 and Figure 1 (A and B), it is observed that the behavior of the two populations (UFLA - E cycles 1 and 2 and UFLA - R cycles 1 and 2) in a general way was quite similar, with the exception of the PE trait, and that the population UFLA - R had a better response. Consequently, keeping these populations separated is unjustified, if only so as to verify the behavior of the populations in future cycles in regards to the PE trait. 

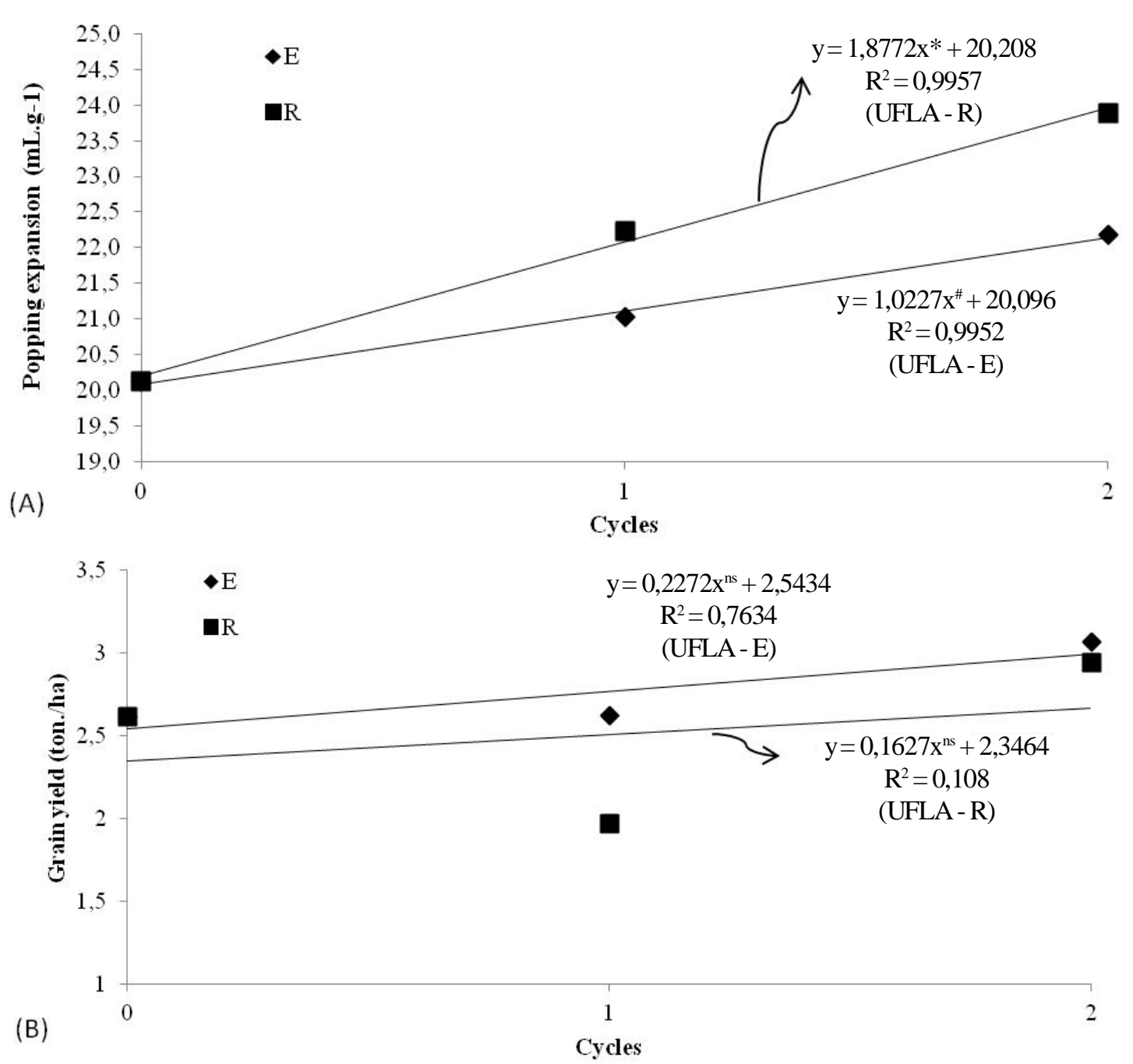

Figure 1 - Regression analysis for the mean popping expansion (A) and grain yield (B) data of the populations UFLA, UFLA-E (cycles 1 and 2) and UFLA - R (cycles 1 and 2), Lavras, MG, in the crop year 2008/09. " ${ }^{\text {s }}$ * and ${ }^{\#}$ : not significant, significant at $5 \%$ and $10 \%$, respectively, by the $t$ test.

\section{CONCLUSION}

There was a gain for the traits studied in the different recurrent selection cycles; the type of kernel (pearl and rice) had an influence on the genetic progress response for PE and GY traits; also the populations assessed exhibit potential for future selection cycles, both for agronomic aspects and for popcorn quality aspects.

\section{ACKNOWLEDGEMENTS}

To the CNPq for providing a scientific initiation fellowship, to the Federal University of Lavras (UFLA) for allowing us to use their infrastructure, and to the Genetics
Sector of UFLA for financial support in carrying out the present study.

\section{REFERENCES}

CRUZ, C. D. Programa Genes: análise multivariada e simulação. Viçosa, MG: UFV, 2006. 175 p.

DAROS, M; AMARAL JÚNIOR, A. T.; PEREIRA, M. G. Genetic gain for grain yield and popping expansion in full-sib recurrent selection in popcorn. Crop Breeding and Applied Biotechnology, Londrina, v. 2, n. 3, p. 339344, 2004a. 
DAROS, M. et al. Correlações entre caracteres agronômicos em dois ciclos de seleção recorrente em milho-pipoca. Ciência Rural, Santa Maria, v. 34, n. 5, p. 1389-1394, set./out. 2004b.

FREITAS JÚNIOR, S. P. et al. Genetic gains in popcorn by full-sib recurrent selection. Crop Breeding and Applied Biotechnology, Londrina, v. 9, n. 1, p. 1-7, May 2009.

HALLAUER, A. R.; CARENA, M. J.; MIRANDAFILHO, J. B. Quantitative genetics in maize breeding. Ames: Iowa State University, 2010. 663 p.

MATTA, F. P.; VIANA, J. M. S. Testes de capacidade de expansão em programas de melhoramento de milho pipoca. Scientia Agricola, Piracicaba, v. 58, n. 4, p. 845$851,2001$.

MATTA, F. P.; VIANA, J. M. S. Eficiências relativas de seleção entre e dentro de famílias de meios-irmãos em população de milho-pipoca. Ciência e Agrotecnologia, Lavras, v. 27, n. 3, p. 548-556,maio/jun. 2003.

NOGUEIRA, M. C. F. Experimentação agronômica I: conceitos, planejamento e análise estatística. Piracicaba: FEALQ, 2007.479p.

PACHECO, C. A. P. et al. Avanços no processo seletivo da variedade de milho pipoca BRS Angela. Revista Brasileira de Milho e Sorgo, Sete Lagoas, v. 4, n. 3, p. 436-444, 2005.

PATERNIANI, E. Métodos tradicionais de melhoramento de milho. In: BULL, L.T.; CANTARELLA, H. (Ed). Cultura do milho: fatores que afetam a produtividade. Piracicaba: Potafós, 1993. p. 301.

RANGEL,R. M. et al. Análise biométrica de ganhos por seleção em população de milho pipoca de quinto ciclo de seleção recorrente. Revista Ciência Agronômica, Fortaleza, v. 42, n. 2, p. 473-481, abr./jun. 2011a.

\section{RANGEL,R. M.; AMARALJÚNIOR, A. T.; FREITAS} JÚNIOR, S. de P. Associação entre características agronômicas e capacidade de expansão em população de milho pipoca sob seleção recorrente. Ciência e Agrotecnologia, Lavras, v. 35, n. 2, p. 225-233, mar./abr., $2011 b$.

RAMALHO, M. A. P.; FERREIRA, D. F.; OLIVEIRA, A. C. Experimentação em genética e melhoramento de plantas. Lavras: UFLA, 2005, 322p.

RESENDE, M. D. V.; DUARTE, J. B. Precisão e controle de qualidade em experimentos de avaliação de cultivares. Pesquisa Agropecuária Tropical, Goiânia, v. 37, n.3, p. 182-194, set. 2007.

SANTOS, F.S. et al. Genetic gain prediction of the third recurrent selection cycle in a popcorn population. Acta Scientiarum Agronomy, Maringá, v. 30, n. 5, p. 651-658, 2008.

SAWAZAKI, E. et al. Potencial de híbridos temperados de milho pipoca em cruzamentos com o testador semitropical IAC 12. Revista Brasileira de Milhoe Sorgo, Sete Lagoas, v. 2, n. 2, p. 61-70, 2003.

SCAPIM, C. A. et al. Componentes genéticos de médias e depressão por endogamia em populações de milhopipoca. Ciência Rural, Santa Maria, v. 36, n. 1, p. 36-41, jan/fev. 2006.

SCOTT, A. J.; KNOTT, M. A. A. A cluster analysis method for grouping means in the analysis of variance. Biometrics, Raleigh, v. 30, n. 3, p. 507-512, 1974.

VENCOVSKY, R.; CRUZ, C. D. Comparação de métodos de correção do rendimento de parcelas com estees variados. I. Dados simulados. Pesquisa Agropecuária Brasileira, Brasília,v. 26, n. 8, p. 647 -657, ago. 1991.

VIANA, J. M. S. Melhoramento intrapopulacional recorrente de milho-pipoca, com famílias de meiosirmãos. Revista Brasileira de Milho e Sorgo, Sete Lagoas, v. 6, n. 2, p. 199-210, 2007.

VIEIRA, R. A. et al. Desempenho agronômico de novos híbridos de milho-pipoca no Noroeste do Estado do Paraná, Brasil. Acta Scientiarum Agronomy, Maringá,v. 30, n. 1, p. 29-36, jan. 2009. 